\title{
Az intelligens otthon jövőképe
}

Az otthon intelligenssé tételének első lépése az automatizálás. Intelligens otthonról akkor beszélünk, amikor a már automatizált egységek vagy alrendszerek nagyobb rendszerbe kapcsolódnak, előre programozhatóvá válnak és egymásra is hatnak. A külső és belső környezet egyes paramétereinek változására más paraméterek megváltoztatásával reagálnak (a termosztátok automatikusan szabályozzák a hőmérsékletet, a füstdetektor vészjeleket ad le a tűzoltóknak stb.). Az intelligens otthonban az egyetlen rendszerbe összekapcsolt modern infokommunikációs technológiák segítik az otthon végzett hagyományos és új típusú tevékenységeket egyaránt. Biztosítják az energiatakarékosságot, elvégzik a biztonsági és riasztórendszerek szabályozását és lehetővé teszik a szórakozást, a táv-betegápolást, az idősek és mozgáskorlátozottak felügyeletét, valamint az otthoni munkavégzést is.

Kulcsszavak: intelligens otthon, intelligens ház, IKT, energiatakarékosság, távmunka, otthoni szórakozás

\section{Szerzői információ:}

Kömlödi Ferenc

Technológiakutató, tanulmányait az ELTE Bölcsészettudományi Karának magyar és tibeti szakán és a dániai European Film College-ban végezte. Jelenleg a mesterséges intelligenciának szentelt elsô magyar portál (www.agent.ai) szerkesztóje, az NHIT IT3 projektjének (http://www.nhit-it3.hu) munkatársa. Jelentôsebb publikációi: Holdfogyatkozás (2002, Kávé Kiadó), Az amerikai némafilm (1999, Magyar Nemzeti Filmarchívum), Fénykatedrális - technokultúra 2001 (1999, Kávé Kiadó).

Kós a Zsuzsa

Okleveles villamosmérnök, mérnök-közgazdász, pályáját a Távközlési Kutató Intézetben kezdte, majd a '90-es évek elején a Matávnál lett stratégiai tervezô. 1996-tól a Hírközlési Felügyeletnél igazgató, 2004-tốl pedig a Nemzeti Hírközlési Hatóságnál a Külsố Kapcsolatok osztályvezctốje. Ezek mellett többek között a Budapesti Múszaki és Gazdaságtudományi Egyetem Távközlési és Médiainformatikai Tanszékének oktatója és a Hírközlési és Informatikai Tudományos Egyesület mobiltelefonok élettani hatásaival foglalkozó munkacsoportjának tagja. Szakterületei: szabályozás, jövốkutatás, infokommunikáció-menedzsment, ágazati és vállalat-gazdaságtan, közszolgálat, nemzetközi kapcsolatok.

\section{Így hivatkozzon erre a cikkre:}

Kósa Zsuzsa, Kömlődi Ferenc. „Az intelligens otthon jövőképe”.

Információs Társadalom VIII, 1. szám (2008): 45-58.

$\Longrightarrow$ https://dx.doi.org/10.22503/inftars.VIII.2008.1.5

A folyóiratban közölt müvek

a Creative Commons Nevezd meg! - Ne add el! - Így add tovább! 4.0

Nemzetközi Licenc feltételeinek megfelelően használhatók. 
Kósa Zsuzsa - Kömlôdi Ferenc

\section{Az intelligens otthon jövóképe}

Tézis: Az intelligens otthon ma még elkülönüló funkciócsoportjai - épiuletgépészet, biztonságtechnika, szórakoztatás, munkahely, szociális funkciók - közös technológiákba integrálódnak és terjednek.

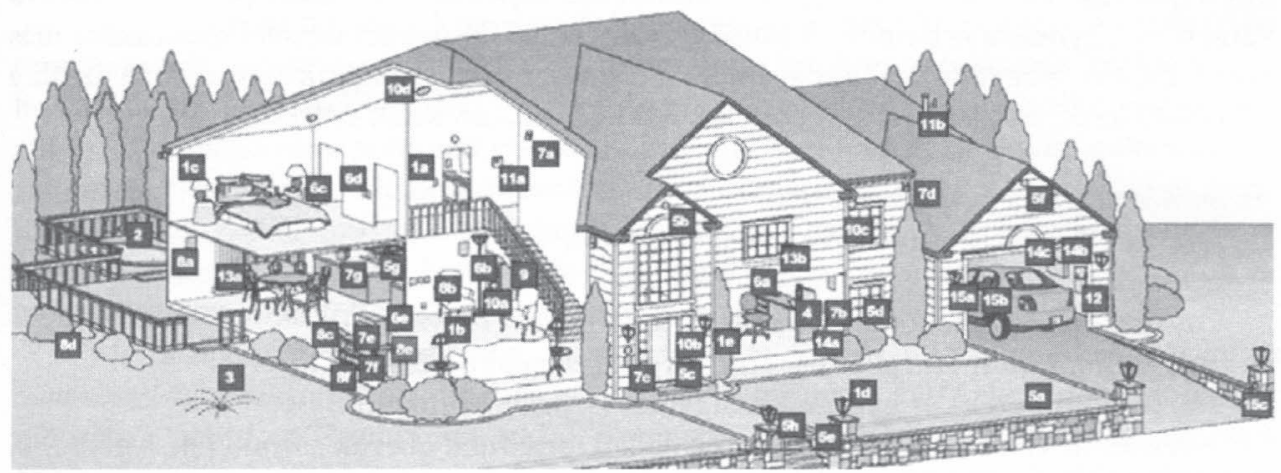

1 VILÁGÍTÁSVEZÉRLÉS

2 MEDENCE, GYÓGYFÜRDÖ

3 ÖNTÖZŐRENDSZER

4 SZÁMÍTÓGÉP- ÉS AUTOMATIZÁLÁSVEZÉRLÉS

5 SZENZOROK

6 TELEFONOK, KOMMUNIKÁCIÓS ESZKÖZÖK

7 VIDEÓ ÉS KAMERÁK

8 AUDIÓ

9 VEZETÉKEK KEZELÉSE

10 BIZTONSÁG KÖRNYEZETVEZÉRLÉS

11 KÖZPONTI PORSZÍVÓRENDSZER

12 ABLAK- ÉS FÜGGÖNYVEZÉRLÉS

13 ELEKTROMOS VEZETÉKEK SZABÁLYOZÁSA

14 GÉPJÁRMỨVEK

(Forrás: Home Controls Inc.) 


\section{Mi az intelligens otthon?}

A lakóhely (lakóépület, lakás, lakrész) - mint épített és berendezett emberi környezet - új munkavégzési és ügyintézési funkciókkal bôvül, és a korábban meglévố funkciók IKT-alapú megoldásokkal válnak hatékonyabbá, biztonságosabbá.

Intelligencián nem bináris változót, hanem a környezetét valamilyen úton-módon érzékelő, annak mindenkori helyzetétól függően döntést hozó, döntését kommunikáló, adaptív és adaptálható rendszereket értünk.

Az otthon intelligenssé tételének elsó lépése az automatizálás. A hagyományos berendezések informatizálása növeli egyedi feldolgozó-, tároló- és kommunikációs kapacitásukat. Intelligens otthonról akkor kezdünk el beszélni, amikor a már automatizált egységek vagy alrendszerek nagyobb rendszerbe kapcsolódnak, elöre programozhatóvá válnak, és egymásra is hatnak. A külsố és/vagy belsố környezet egyes aspektusaira más aspektusokat megváltoztatva reagálnak: a termosztátok automatikusan szabályozzák a hómérsékletet, a füstdetektor vészjeleket ad le a túzoltóknak stb.

Az intelligens otthon funkciócsoportjai:

a) intelligens (környezetre reagáló) épület,

b) biztonságtechnika és vagyonvédelem,

c) otthoni szórakoztatás, vásárlás és ügyintézés (fogyasztás),

d) otthoni munkavégzés és tanulás (gazdasági aktivitás),

e) otthoni beteg- és gyermekfelügyelet (szociális funkciók).

A lakóhelyek egyre nagyobb hányadában terjednek el ezek a funkciók, a hozzájuk kapcsolódó háttérszolgáltatásokkal együtt. Egy-egy otthonban a felhasználó igényeitól függően körülbelül kettő-három jelenik meg közülük, késóbb három-négy, végül általánossá válik négy-öt funkciócsoport megléte. Az egyes funkciók IK'T-alapú megoldásokkal válnak hatékonyabbá és biztonságosabbá.

A házakkal kapcsolatos intelligenciafunkciók csoportosíthatók, és a szükségleteknek, illetve a lehetőségeknek megfelelően alkalmazhatók. A vezérlőegység által automatikusan végrehajtott és a lakók által alkalmanként, akár távolról megvalósított folyamatok megkülönböztethetốk egymástól. A távolról történố vezérlés sikeres kivitelezéséhez azonban a maiaknál sokkal pontosabb és megbízhatóbb távérzékelókre van szükség.

A továbbra is mindig az ember által irányítandó és a félig vagy teljesen automatizált eszközök két külön csoportba tartoznak. Emberi irányítással múködik például a mobiltelefonos hívásra is funkcionáló garázsnyitó. Teljesen automatizáltak lehetnek például a kritikus alatti szinteket jelzó, internethasználatra is alkalmas digitális hútógépek.

A háztartási-szórakoztató és az egészségügyi funkciók viszonylagosan elválnak egymástól. Az intelligens otthon jelenlegi jövóképei általában e két fő csoport körül rajzolódnak ki, vagy az egyikre, vagy a másikra fókuszálva, de viszonylag kevés az olyan leírás, amelyben a kettố együtt, „egymásba integrálva” szerepelne.

A biztonsági funkciók megerősödését a vagyonvédelem indokolja. Az otthonokba kihelyezett munkavégzés biztonsága és adatvédelme megerósíti ezt az igényt. Az otthoni betegfelügyelet szintén különös érzékenységet kíván ezen a területen. Az 
internetalapú és egyéb, hálózatba kötött biztonsági rendszerek által végzett monitorozás rendeltetésszerúen biztonsági célokat szolgál, ám ha több ennél, zavaróvá válhat, mert sértheti a magánélet zavartalanságának jogát. A biztonsági szolgáltatások azonban nemcsak informatikai megoldásokat jelentenek, hanem mindenféle személyes beavatkozásra képes háttérszolgáltatókat is (például vagyonvédelmi vagy egészségügyi riasztások esetében). Az ilyen jellegú funkciók megerősödését láthatjuk az új kertvárosi negyedekben (például Budapest egyes lakóparkjaiban), valamint a városrehabilitáció területein.

\section{- Infokommunikációs megoldások}

Az intelligens otthonnak az a rendeltetése, hogy a lehetóleg egyetlen rendszerbe összekapcsolt, együttesen felhasználható modern infokommunikációs technológiák hozzáférhetók legyenek az otthon végzett hagyományos és új típusú tevékenységek során is. Különbözố szempontokat igyekszik kielégíteni, ideértve az energiatakarékosságot (a világítás, a fútés, a légkondicionálás stb. automatizálásával), a biztonsági és riasztórendszerek szabályozását, a szórakozást (az otthon mint szórakoztatóközpont és az információhoz való állandó hozzáférés biztosításával), a távbetegápolást, az idôsek és mozgáskorlátozottak felügyeletét, valamint az otthoni munkavégzést.

Mindezek megvalósításához a „mindenütt jelen lévô számítástechnika” (ubiquitous computing) és a környezetintelligencia- (ambient intelligence, AmI) alapú rendszerekhez hasonló, a következô komponensekból összeálló „intelligencia” szükséges: szenzorok és aktuátorok (például bioszenzorok és mikroaktuátorok is), kommunikációs infrastruktúra, szoftverkontroll-infrastruktúra (az utóbbiban fontos szerephez jutnak az ágensek).

Az Aml a körülöttünk lévố tárgyakba ágyazott komoly kapacitású, intuitív interfészeivel járul hozzá a koncepció (ambient and assisted living) megvalósulásához, és biztosítja, hogy a környezet „észrevétlenül” felismerje a jelenlévóket, reagáljon rájuk.

A mikroszenzorokhoz és aktuátorokhoz, valamint az általuk alkotott szenzorhálózatokhoz idővel a mikro-elektromechanikai rendszerekbe (MEMS) integrálandó, ma még inkább kísérleti stádiumban lévő, „okos”, például a hớmérsékleti változások hatására rendkívuiili mértékben táguló, illetve összehúzódó, de a hốmérséklet normalizálódásával normális méreteiket visszanyerố anyagokat, például alakemlékezố ötvözeteket használnak fel.

Az intelligens otthon létrejöttéhez szükség van továbbá egyszerúbben igénybe vehetố vezetékes és vezeték nélküli kommunikációs szolgáltatásokra, valamint a tárgyak tulajdonságainak és a személyek várható viselkedésének modellezésére is.

\section{- Épitészeti megoldások}

Az infokommunikációs feladatok megoldása mellett különféle (külsố és belsố) építészeti feltételek biztosítására is szükség van. Neves építészek szerint az intelligens otthon és az építészet kapcsolatát elsôsorban funkcionális szempontból célszerú vizsgálni. A kortárs építészet egyrészt egyre takarékosabb alapterületet alakít ki, melyet 
gazdasági szempontok diktálnak, másrészt mind differenciáltabb igénysort elégít ki, ami változó és gazdagodó igényeinkból származik. Ezek a feltételek ellentmondanak egymásnak, s a hagyományos építészeti felfogással nehéz a szempontokat egymásnak megfeleltetni.

A korai '80-as években beszéltek elôször intelligens épületekról. A meghatározás a kapcsolódó technológiák és a környezet változó igényeinek fejlődésével változott. Három szakaszt különböztetünk meg: 1985-ig a múködést automatikusan kontrolláló, 1992-ig a megváltozott körülményekre válaszoló, 1992-tól pedig az igényeket hatékonyan kielégító épületeket értettünk, illetve értünk ma rajta. Az épületeknek produktívnak, biztonságosnak, egészségesnek és minden szempontból kényelmesnek kell lenniük. Alapfeltétel, hogy potenciálisan több generációt szolgáljanak ki: könnyen karban lehessen tartani óket, alkalmazkodjanak, ne okozzanak környezeti és földfelszín alatti (például az energia- és az ásványi forrásokat érintô) károkat. Mindezt természetesen maximalizált hatékonyság, minimalizált kiadások és a négy alapkomponens - szerkezet, rendszerek, szolgáltatások, kezelés - optimalizálása mellett.

A technológiai kínálat lehetốvé teszi, hogy az intelligens otthon funkciói kialakuljanak régi épületekben is. Ezek elsôsorban a meglévố hálózati infrastruktúrákra (kábeltévére, telefonra) vagy vezeték nélküli hálózatokra épülhetnek. A régi épületekben a szenzorokon alapuló épületgépészeti megoldások a legköltségesebbek - ilyen például a fútés, a világítás és az alternatív energiaforrások illesztése a meglevô (gyakran elavult) rendszerekhez.

Az újabb épületek esetében valószínúsíthető a lakóparkok koncepciójának kiterjesztése ebben az irányban is: az otthon ,intelligenciája” beépül az épületekbe, és az épületegyüttes üzemeltetốje szolgáltatásként nyújthatja a funkciók nagy részét (például fütésprogramozás, biztonsági kamerák, videotartalom-szolgáltatás, internetszolgáltatás, betegfelügyelet).

\section{Kulcstényezők és hajtóerők}

A kínálati oldalon már léteznek az intelligens otthon építóelemei. A beágyazott rendszerek közé tartoznak a vezérelhetô épületgépészeti eszközök. A környezet elemeihez sorolható a szenzorok, mozgásérzékelók, riasztók és webkamerák csoportja. A programozható médiainformatikai eszközök már régóta részei az otthonoknak. A személyi számítógépek és a lakáson belüli hálózatok nemrég váltak otthoni eszközökké. A $2 \mathrm{MB} / \mathrm{s}$ körüli adatátviteli sebesség (ADSL vagy kábeltelevíziós) internetkapcsolat már nem különlegesség, és az átviteli sebesség kb. $10 \mathrm{MB} / \mathrm{s}$-ig növelhetô a mai technikai szinten is.

A kínálat egyes elemeivel részletesen foglalkozott az NHIT-IT3 tanulmány (II. kötet) néhány mélyfúrása a végberendezések sokszínúsége, a szenzorok, az ember-gép kapcsolatok és a tartalomszolgáltatások témaköreiben. (Készülóben vannak például a beágyazott rendszerekre vonatkozóan további mélyfúrások is, amelyek szintén a technológiai kínálat fejlődését tárják fel.)

A keresleti oldalon több társadalmi, gazdasági és fizikai folyamat együttes hatása figyelhető meg. Az idősek háztartásaiban egyre nagyobb az igény a könnyen kezelhetô, 
biztonságos eszközökre és egyes betegfelügyeleti riasztásokra. A fogyatékkal élók önálló életvezetési igényei vezérelhetố manipulátorokkal kielégíthetók lennének. A kereslet jelentôs eleme a jól keresố, de sokat dolgozó rétegek gépesített háztartása. Ezekben a rétegekben sok az egyszemélyes háztartás. Növekszik a gyermeküket egyedül neveló szülók és az „egy szülố- néhány gyermek” típusú háztartások száma. Mindezt kiegészítik a lakásban megszervezett családi vállalkozások, amelyek - függetlenül a családszerkezettól - „hazaviszik” a munka funkcióit. A második otthonként kiépített, távolról vezérelhetô nyaralók elsôsorban biztonsági funkciókat igényelnek.

A keresletnek van egy eleme is, amely a közeljövóben fog megmutatkozni: középtávon már nyugdíjaskorba lép az elsố olyan generáció, amelyik jelentốs mértékben használ számítógépeket a munkahelyén. Ebból adódóan a felhasználók tapasztalatlansága többé nem korlátozza az informatikai eszközök otthoni terjedését. A „hatvanasok-hetvenesek" továbbfoglalkoztatása részmunkaidóben és távmunkaeszközökkel lehetségesnek túnik egyes társadalmi csoportokban. Ez egyrészt gazdasági elốnyökkel járna, másrészt terheket venne le a szociális rendszerról is.

E mindennapi jelenségek mögött a háttérben további hajtóerók is szerepelnek, amelyek megváltoztathatják az otthon funkcióit. Az energia ára sokkal drágábbá teheti a közlekedést és ösztönözhet az energiatakarékos megoldásokra, így az intelligens otthon helyettesítố szolgáltatásokat épít be a mai közlekedés (például az agglomerációs ingázás) egy része helyett.

A társadalmi szolgáltatások átrendeződése az otthon funkcióinak teljes újragondolását hozhatja magával: például a lakóhelyen megvalósuló betegápolás kényelmesebb lehet a kórházinál, és a felnóttkori tanulás is nagyrészt megoldható otthonról. A harmadik háttértényezố a közbiztonság állapota, amely esetleg romolhat, és szükségessé teheti az otthonok hatékonyabb és fokozottabb védelmét. A romló közbiztonság abban az irányban hathat, hogy az emberek egyre többet tartózkodnak az otthonaikban, illetve védett lakóközösségekben.

\section{Jövőképek}

A funkciócsoportok és a kulcstényezók, valamint a hajtóerơk fïggvényében három fejlödési visió vázolható fel.

A három fejlódési vízió gyakorlatilag három dimenzióként is felfogható, mert a valóság várhatóan ezeknek a tényezóknek valamilyen kombinációjából fog összeállni. A három alternatíva annyiban különbözik egymástól, hogy melyik elemet tekinti dominánsnak a jövốt illetốen. A társadalom különbözố csoportjai számára valószínúleg más-más elem lesz a meghatározó.

\section{- A kinálatvezérelt fejlốdés víziója}

A jelenlegi tendenciák kivetítése azt mutatja, hogy a piac kínálatvezérelt módon fejlődik. Ami technikailag lehetséges és nem túl drága, az elkezd terjedni, mert igény van rá. A növekvő igény méretgazdaságossá és így olcsóbbá teheti a kínálatot, beindul a 
fejlődési spirál felfelé. Az igények spontán változása összefügg a demográfiai mutatók, a családszerkezet és az életmód változásával. A folyamat a módosabb rétegek háztartásainál indul; hangsúlyossá válnak a biztonsági és vagyonvédelmi igények.

A kínálat technológiai alapját az képezi, hogy az elektronikus technológiák integrálódnak, hálózatba kapcsolódnak és egyre interaktívabbá válnak. A rendszerekbe beépítik a lakókhoz alkalmazkodó tanulás képességét, ami idoóvel egyfajta „aktív intelligenciát" eredményezhet. A széles sávú kapcsolódások terjedése és a vezeték nélküli adatátviteli sebesség növekedése könnyen és rugalmasan kapcsolja az internethez az otthonokat. Mindezek következtében a lakószobák digitális szórakoztatóközponttá vagy otthoni munkahellyé válnak. A háztartás egészében megjelennek olyan multifunkcionális berendezések (például hútôszekrények, fürdôszobatükrök stb.), amelyek egyrészt vezérelhetốk, másrészt visszajelzést adnak a saját állapotukról a vezérló felé.

Az otthoni szórakozás, a munka és a háztartási gépesítés intelligencia-csomópontjainak fokozatos technológiai egyesülése várható. Ehhez kapcsolódóan a fizetóképes háztartásokat kielégítő differenciált szolgáltatások jelennek meg. Az otthonhoz kötôdő sok külsố szolgáltatással az informatizált eszközök tartanak mindennapi kapcsolatot. Így lehet testre szabottan kiszolgálni az egyszemélyes (,szingli-”) vagy csak néhány elfoglalt felnốttból álló háztartásokat és a lakásba szervezett családi vállalkozások szerteágazó igényeit. Az új infokommunikációs rendszerek azt is lehetôvé teszik, hogy a világ bármely pontjáról - telefonon vagy számítógépen keresztül - irányíthassuk a lakásunkban múködő berendezéseket és a beépített biztonsági funkciókat.

A jövedelemszerzési mód és a valós jövedelmi helyzet erôsen befolyásolja a lakásokba beépülő funkciókat, a külső szolgáltatások iránti igényeket és az otthon intelligenciaszintjét.

\section{- Aszociális funkciók víziója}

Az egészségügy átszervezésével differenciált és öngondoskodásra (például egészségpénztárakra, biztosítókra) épülố betegellátás várható. Az érintettek anyagi megfontolásai hangsúlyosabbak lesznek, és az otthoni betegfelügyelet sok család számára elérhetóbbé vagy vonzóbbá válik a kórházi megoldásoknál. A rendszer tényleges múködéséhez a háttérben ki kell épülnie egy megbízható egészségügyi szolgáltató rétegnek.

Az intelligens otthon mint távbetegápolási környezet kialakításának az a célja, hogy az idốsek és a betegek (mozgáskorlátozottak, krónikus betegségekben szenvedók stb.) minél tovább, minél nagyobb kényelemben és a lehetôségekhez képest önállóságukat megốrizve élhessenek megszokott környezetükben. Lakásaiknak sürgốsségi, azonnali beavatkozást igénylő szempontoknak is meg kell felelniük. Mindez speciális intelligenciafunkciók bevezetését, ellenơrzött és részben irányított környezet kialakítását, esetleg robotok használatát teszi szükségessé.

A távirányított betegellátás hosszabb távon fontos változásokat idéz elô az egészségügyben: a hangsúly a kisebb kiadással járó megelơzésre és az otthoni kezelésre tevődik át, biztosítva, hogy a beteg kevésbé érezze magát kiszolgáltatottnak.

Az infokommunikációs technológiákra épülő betegfelügyeleti megoldásokat az állami szociális rendszer és a várhatóan megjelenố magán-betegbiztosítók különbözố 
ütemben és mértékben fogadják be. Így a folyamat valószínúleg a középrétegekhez tartozó idősek és fogyatékkal élók háztartásaiban indul meg, de felgyorsulhat, ha a szociális rendszer - a társadalmi vagy magánmegtakarítások mértékéig - hozzájárul az intelligens otthon terjedéséhez.

Az otthon szociális funkcióinak újragondolása nem csak a betegápolásra terjed ki. Várható az intelligens alrendszerek és a lakásban élő személyek közvetlenebb interaktív kapcsolata - még akkor is, ha a személyek éppen nem tartózkodnak otthon. Lehetségessé válik intelligens ruházatuk vagy személyazonosítójuk érzékelése és az erre való reagálás. A virtuális vagy kibóvített valóság az intelligens otthon egyik eszköze lehet, amely gördülékenyebbé teszi a személyek közötti kapcsolatot, vagy betegek gyógyulását segíti eló, és egyes készségek fejlesztésében is szerepet játszhat. A betegek, idősek és fogyatékkal élók, esetleg a fiatalkorúak segítésében is elótérbe kerülhetnek a háztartási robotok, amelyek elvégzik eleinte csak a fúnyírási és takarítási feladatokat, majd segédkezhetnek a bevásárlásnál vagy a gyerekek szemmel tartásában, és monitorozhatják az idôsek és fogyatékkal élók életvitelét is.

\section{- Az energiagondok víziója}

A szénhidrogén-alapú energiahordozók magas ára és különféle környezetvédelmi intézkedések (például az üvegházhatású és egyéb káros gázok drasztikus mértékú redukciója) miatt az energiaigény optimalizálása érdekében intelligenciafunkciókat kell beépíteni az épületgépészeti megoldásokba. A tervezók integrálják az épületekben az üveg-és falfelületek aktív hôvezetését, az időjárás-előrejelzések függvényeként kialakítandó megelốzô stratégiákat és a hibafelderítést. A fútés időalapú szabályozásával, új világításés légkondicionálás-irányítási módszerekkel takarékosabb energiafelhasználás érhetô el. Az alternatív energiaforrások használata egyes háztartásokon belül szükségessé teszi, hogy intelligens vezérléssel váltson az otthoni rendszer a különbözố energiaforrások között (például napelemes fútés mellé gázfưtés is induljon). Az energiamegtakarításokhoz állami környezetvédelmi támogatások is kapcsolódhatnak. Mindezzel „passzív intelligencia”, azaz reagálási képesség jön létre a házak és a lakások gépészeti vezérlésében.

A kiskereskedelmi energiapiacok liberalizálása további lökést adhat az intelligens otthonok fejlődésének, hiszen a háztartásoknak már nemcsak a fizikai, de a gazdasági környezethez is alkalmazkodniuk kell (például interneten keresztül figyelt energiaárak alapján kell lekötni a következó idốszak villany- vagy gázfogyasztási kvótáit).

A magas benzinárak jelentôs mértékben növelik a közlekedési és szállítási költségeket. Ezzel párhuzamosan a távközlési költségek viszonylag alacsony szinten maradnak. Ez a folyamat átrendezôdést okoz a fogyasztásban. A személyes közlekedés helyett internetes vásárlás, ïgyintézés és otthoni szórakozás válik általánossá. Aki teheti szintén az interneten keresztül - a lakóhelyéról fog dolgozni. Az otthonokba közvetlenül szállítják ki az árukat a megrendelések alapján. Ezzel összefüggésben várhatóan visszaáll az otthoni élelmiszer-raktározás korábban megszokott szintje. A társadalmi kapcsolatok fenntartása terén is elótérbe kerülnek a kommunikációs hálózatok. Ez a folyamat várhatóan a kertvárosokban válik majd elốször érzékelhetố, ahová városi munkavégzésre épülő háztartások telepedtek ki, ám az ingázás egyre költségesebbé válik. 
Az energiagondokon kívül hasonló hatásokkal járhat a biztonsági szint csökkenése vagy a természeti környezet állapotának jelentôs romlása is. Ezek a problémák egyértelmúen a közlekedési aktivitás csökkenéséhez és infokommunikációs megoldásokkal való helyettesítéséhez járulnak hozzá.

\section{Narratívák}

Az alábbiakban négy megjelenített jövókép-narratívát adunk közre. Olyan fantázia szülte jövóbeli szituációkat mutatunk be, amelyekben - várhatóan körülbelül 8-10 év múlva - a hétköznapi ember találhatja magát. A megjelenítés mögötti technológiai kínálat vagy társadalmi munkahipotézis leírása a lábjegyzetekben található.

1. példa: jól kereső, kötetlen munkaidejú szingli hétköznapja 2015-ben

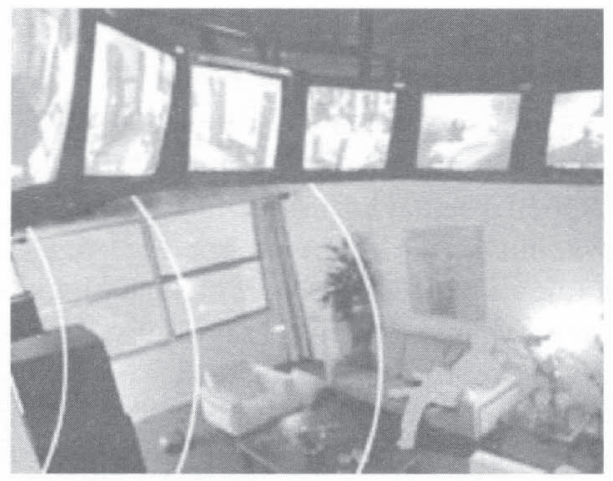

Reggel késôn ébredt Szilárd, aki infobróker (régebben talán könyotárosnak mondták volna, ma inkább információvadász). Hajnalban fekiüt le, mert dolgozott a gépén.

Reggel 9-re idósitett kávéja és az otthon sült zsemléje már rég kihült: éjjel elfelejtette átprogramozni.

A terasz ajtaján megjelent a meteorológiai elórejelzés. ${ }^{2}$ A mai nap szép idóvel indul, de délutánra vihar várható. A pici télikert még vizes volt a reggeli öntözéstól, délután az automatikus mozgójárda majd beviszi a virágokat védettebb helyre. ${ }^{3}$

A fürdöszobában a kellemes fürdö után meg kellett hallgatnia a nem annyira kellemes hírekkel szolgáló elektronikus egészségi tanácsadóját: ${ }^{4}$

„A súlyod nôtt egy kilóval, a vércukrod a határértéken van, és a vérnyomásod sem megfeleloó. Ráadásul a tüdódben már megint nikotint találtam. Ha ezt így lejelentem az egészségbiztosítónak, megint megemeli 20 százalékkal a dijadat. ${ }^{5}$ Rendelek neked egy tisztítókúrát. ${ }^{6}$ OK?

\footnotetext{
${ }^{1}$ Idốzített kávéfốzô és kenyérsütő a háztartás-menedzseló program irányításával.

${ }^{2}$ Falra vagy bármely felületre kivetíthetố idôjárás-előrejelzố tartalomszolgáltatás.

${ }^{3}$ Olyan, idôjárás-érzékelố szenzorra épülő és az épületmenedzser-program irányításával múködổ öntözố- és árnyékoló rendszer, amelynek az elemei már ma is léteznek.

${ }^{4}$ Az egészségi állapot jellemzóit (testmagasság, súly, vérnyomás, szívritmus, vérzsír- és lehelet-összetétel) komplexen felmérô eszköz. Ilyen eszköz ma is létezik a patikákban, háztartási változatának megjelenése a közeljövóben várható.

${ }^{5}$ A magán-egészségbiztosítás díjszabása várhatóan követni kívánja az egészségügyi kockázatok változását.

${ }^{6}$ A külső egészségügyi szolgáltatók sztenderd szolgáltatásokra az interneten keresztül is elfogadnak megrendeléseket, például léböjtkúrára vonatkozó tanácsadás és a hozzá szükséges termékcsomag megrendelését.
} 
A háztartásmenedzser (egy láthatatlan, de hallható szoftverágens) megvárta, míg elhelyezkedik Szilárd a nappaliban, majd fennhangon rákezdte:

„Az éjjel betörési kísérlet volt a hátsó kapunál, de meghiuisítottam. ${ }^{8}$ Az energiaárak lementek a szomszéd országban, úgyhogy télire rendeltem pár ezer $k W h-t .{ }^{9}$ A programod szerint ${ }^{10}$ ma vendég jön. Milyen ételt rendeljek az étteremból?

Az üzleti menedzser ${ }^{11}$ (az elöbbi ágens párja) átvette a szót a háztartási menedzsertól:

„Az adóhivatal ellenórzi a számláidat és a bevallásaidat. Eiddig minden rendben, de még csak a muilt hétnél tartanak. A szerzódésállományod likviditási mélypontot jeles pont novemberre, amikor sokat szoktál költeni."

„Elég volt belóletek, szórakozni vágyom!” - kiáltott fel Szilárd. Eirre a falon megjelent a számára elérhetó kínálat: ${ }^{12}$

„Nézhetsz régi filmet, játszhatsz velem vagy másokkal, és hallgass zenét, az mindig jót tesz. Vagy gyere tornázni, tugyis rád fér:"

A kapcsolatmenedzser ${ }^{13}$ jelezte, hogy ơ is szeretne kommunikálni a gazdával:

„Új kapcsolatfelvételi igények érkez:tek: régi iskolatársak, haverok, barátok barátai. Az eddigi kapcsolati körben ma három születés-és két néonap van. Elökészitettem az üdvözleteket és a rendelhetó-kïldhetớ ajándékok listáját. Csak döntened kell, kire mennyit szánsz."

Mindezek után Szilárd leiilt a gépéhez, és elkezdett dolgozni. ${ }^{14}$ Ma nem mozdul ki otthonról, mert a tốsdei árfolyamok gyorsan változnak Ausztráliában, és ki kell deritenie, hogy az elemæett információk alapján milyen tanácsot adjon a megbizóinak.

\section{2. példa: krónikus betegségben szenvedô idôs személy hétköznapja 2015-ben}

\section{Rózsi néni nehezen ébredt az ébresztö telefonhivásra.}

Az állapot-ellenörzó ágens ${ }^{15}$ kellemes nới hangon megkérte, hogy álljon rá a mérlegre, mérje meg a vérnyomását és a vércukrát. Az automatikus adagolót' ennek alapján kiadta a napi gyógyszeradagját, neki csak be kellett vennie.

${ }^{7}$ A programozható háztartási eszközök munkáját összehangoló informatizált eszköz (a múltbeli házvezetônók informatizált utódja).

" A biztonsági rendszer kisebb támadások észlelésekor önállóan reagáló izzemmódra áll át, például erősebben bezár és videofelvételt indít, esetleg nehezen lemosható festékkel jelöl.

"A kiskereskedelmi energiapiacok liberalizálásából fakadó tennivaló, amelyet a háztartásmenedzser optimalizál.

${ }^{10}$ Idôgazdálkodási program, amely együttmúködik a kiszolgáló funkciókat ellenốrzô háztartásmenedzserrel.

${ }^{11}$ Az üzleti menedzser a könyvelô, a pénztáros és a titkár funkcióit együttesen betöltố program, amely hatósági kapcsolatok létesítésére is felhatalmazást kapott.

${ }^{12}$ Otthoni szórakoztató funkciók, rendszerbe szedve és kivetítve (a tévé utódjaként).

${ }^{13}$ A kapcsolatmenedzser az ïzleti és magánkapcsolatokért felelôs szoftverágens, amely naprakészen nyilvántartja a címeket, elérhetôségeket, névnapokat, ígéreteket és közös eseményeket. (A notesz és a névjegytartó utóda, ma már megjelent néhány hasonló funkciójú internetes közösségi honlap.)

${ }^{14}$ Otthoni munkavégzés, amely alapvetôen távolról elérhetô információk feldolgozására irányul.

${ }^{15}$ Az otthoni betegápolás állapot-ellenőrző eszköze. Hasonlít az elóbbi példa egészségi tanácsadójához, de nemcsak az egészségbiztosítóval, hanem az egészségi szolgáltatóval is összeköti az otthoni beteget.

${ }^{16}$ A beteg szokásos, orvos által elôírt gyógyszer-kombinációját adagolja ki akkor, ha a beteg egészségiállapot-paraméterei a szokásos értékek között vannak. Kisebb mértékú állapotromlás esetére beállítható többletgyógyszeradagolás is. 
Választania kellett, hogy mit rendel ebédre: nincs étvágya, unja már az étlapot, de a gyümölcsök még nagyon drágák így kora tavasszal. Végül is hagyományos ételt válasætott, amely megjön 11-re a futárral. ${ }^{17}$

Szeretne egy régi filmet megnézni, de csak arra emlékszik, hogy egy igazi nagy sжinész játszott benne, valamikor fiatalkorában: talán Sinkovits vagy Básti? A keresóti húsz film listáját nyomtatta ki, ö nehezen választott közüliik, el is unta hamar.

Sajnos a mozgása és a szeme már nem az igazi, de egészen jól hall az implantált ${ }^{19}$ hallókésziilékével.

Inkább a visszaemlékezófunkciót választotta: hangosan elmondta az életét részletesen. Éppen a 40-50 évovel azelótti idókról mesélt, amikor megérkezett az ebéd. Egy tudásmenedzsment-központ jó pénzt fizet a visszaemlékezéseiért, ${ }^{20}$ jól jön az a nyugdij mellé.

Délután látogató várható, a szociális nóvér, esetleg az orvos is eljön. Rendelt egy kis aprósüteményt és kávét is nekik telefonon, és utasitotta a takaritórobotot, hogy rakjon rendet délutánra. ${ }^{21}$

A lánya felhívta a munkahelyéról: a képet már nehezen látja, akármekkora falfelületre nagyítja is ki, de a hangját jól felismeri. ${ }^{22}$ Este eljön, és elviszi hoz:ájuk vendégségbe, aztán visszahoz:a, mert otthon, a saját ágyában szeret aludni.

Estére azért beindítja a biztonsági örzö rendszert, ${ }^{23}$ mert a bizalom mellett az sem árt.

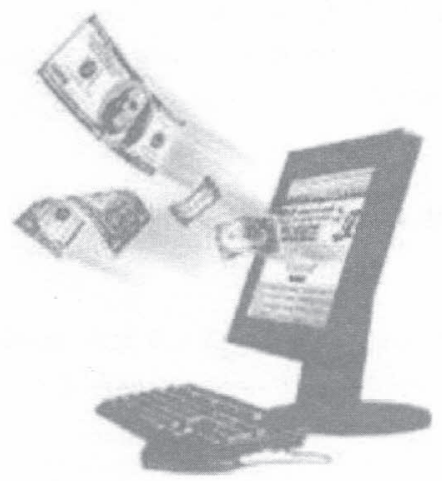

3. példa: távmunkát végzố család reggele 2015-ben

Baloghék reggelenként madárfüttyre ébrednek a kertvárosban. ${ }^{24}$

Máté, az apa kisétál, az interneten nézi meg a reggeli újságot ${ }^{25}$ és átfutja a tózsdei híreket. Észnél kell lennie, mert nyugdij-elótakarékossági alapját részvényekbe fektette, így állandóan figyelnie kell, nehogy elísszon a nyugdijra félretett pénze. ${ }^{26}$

${ }^{17}$ A ma is létező ételfutár-szolgálat továbbfejlesztése napi rendelésre, internetes vagy mobiltelefonos kezelófelülettel.

${ }^{18}$ A video on demand szolgáltatás keresóje, amely közös archívumból szedi ki a szórakoztató tartalmakat különféle kulcsszavak szerint.

${ }^{19}$ Hallókészülék a füle mögé, a bốr alá beültetve. Kis energiaigénye miatt nem igényel elemcserét, a testhốt hasznosítja.

${ }^{20}$ A tudásmenedzsment-központ magánjellegúi információtartalmakat gyújt és archivál, amelyek alapanyagok lehetnek különbözó szakembereknek, például történészeknek a szövegbányászat módszerével végzett elemzéseihez.

${ }^{21}$ Hangalapú ember-gép kapcsolattal múködó komplex háztartási gép vagy robot.

${ }^{22}$ Videofonhívás, falra kivetített képpel.

${ }^{23}$ Speciálisan idôs emberek védelmére szolgáló biztonsági és vagyonvédelmi rendszer.

${ }^{24}$ Baloghék kertvárosban élnek, távmunkában dolgoznak, mert az ingázást nem nagyon engedhetik meg maguknak.

${ }^{25} \mathrm{Az}$ újság tartalma szinte ingyen van, a papír drága, kinyomtatni nem érdemes, az érdekes cikkek elektronikusan archiválhatók.

${ }^{26}$ A nyugdíjalapok különféle kockázati osztályba sorolt befektetéseket tesznek lehetôvé a nagyobb hozam reményében, de a beavatkozás vagy be nem avatkozás kockázatát az érintettnek kell vállalnia. 
Felesége, Aliz fordító, több nyelven tud, de éppen üj forditanivalót keres az interneten. Amióta megjelentek a gépi fordítóprogramok, kevesebb a munka, jobbat kell nyújtani, mint a gépek, ami nem könnyü. ${ }^{27}$

Lányuk, Kata már leiilt a gép elé. Kutatási asszisztensként ${ }^{28}$ dolgozik, most éppen egy marketingtémán. Ki kellene derítenie, hogy van-e még valaki, akinek nincs hosszú távui hitele, és ast is, hogy ki maradt ki a legutóbbi pénzügyi piramisjátékból.

Fiuk, Balázs még csak most tanulja a szakmát. Informatikusnak készül egy távoktatási formában müködó fóiskolán. Most éppen az a feladat, hogy törje fel az iskolai adminisztráció adatbiztonsági rendszerét. Ha sikeriil, visszafizetik az elég magas tandiját, de még az is lehet, hogy valamilyen formában ${ }^{29}$ alkalmazzák.

Az apa megnyugodott, még nem ment tönkre: as ázsiai tóxsdék ugyan most instabilak, de a latin-amerikaiakkal lehet kompenzálni. Kiadja az utasitásokat a bankjának, és elindul a kertjébe almát szedni. A kerti napszámosok jönnek, ${ }^{30}$ segitenek almát szedni. Ók elsösorban mobilon elérhetók, ${ }^{31}$ azon hivhatók, ha kell valami fizikai munka.

\section{4. példa: Energia- és környezettudatos lakóközösség 2015-ben}

Botond, Pitypangtelep polgármestere reggeli körsétájánál tart. A 20 lakóházból álló telepet elektronikus biztonsági rendszer veszi körïl. ${ }^{32}$

Pitypangtelepen önkéntesen odaköltözó, öntudatos környezetvédök élnek, akik a biogazdálkodás mellett többnyire szellemi távmunkát is végeznek. ${ }^{33}$ Közösségi megoldásokat dolgoznak ki a környezet megóvására és az energiatakarékosságra.

- A napelemek csillognak a fényben, a közeli dombokon a törpeszélerömúvek jelsik as idöjárás változását. A közösségi élelmiszerraktárban geotermikus energiával fütenek. ${ }^{34}$

- Az ivóvizkutakat és a szennyvítelepet ellenórzi minden reggel a polgármester, aki szakmája szerint mikrobiológus. Minden rendben, a víz is iható, nem kell fertótlenítốt belekeverni. A szennyviztisztító zárt rendszere biogázt termel, azzal fütenek télen a közösségi házban, nyáron meg palackoz:ák. ${ }^{35}$

${ }^{27}$ A gépi fordítóprogramok gyorsak és olcsók, de nem elég jól tükrözik a kulturális különbségeket. Emiatt a fordítással foglalkozó emberek feladata fóként a lektorálás és a kultúraközi áttételek megoldása.

${ }_{28}^{2}$ Új, most kibontakozó szakma: gyakorlatilag információhalászat és az interneten elérhetố információk strukturálása bármely témában, amely a megrendelót érdekli.

${ }^{29}$ Gyakori tehetségkutató feladat az informatikusok kiválasztásában. Aki fel tudja törni a védelmet, az ért hozzá, és jobbat is tudna készíteni.

${ }^{30}$ Rétegezett társadalomra lehet számítani, a leírt kertvárosi életkörülmények várhatóan a középosztályra lesznek jellemzók. A szegényebb népesség egy része alkalmi munkalehetốséget találhat a kertvárosokban.

${ }^{31}$ A társadalom egészét eléri a keskeny sávú mobiltelefon-szolgáltatás, még az alkalmi munkásokat és a hajléktalanokat is.

${ }^{32}$ Az alternatív életformát folytató faluközösségeknek szükségük van elektronikus biztonsági rendszerre, mert a társadalmi feszültségek között így óvják magukat, tagjaikat és vagyonukat.

${ }^{33}$ Környezetvédô faluközösség ma is van Magyarországon: Gyúrúfü.

${ }^{34}$ Alternatív energiaforrások biztosíthatják az energiaszükséglet nagy részét.

${ }^{35}$ A vízháztartást külön körben kell ellenörizni, mert ez az egészségmegóvás része is. 
Botond beér a hivatalába, amelyet a saját garázsában rendezett be. Benziniizemú gépkocsiját rég eladta, helyette kerékpárral közlekedik, amikor teheti. Ha be kell mennie a közeli városba, elkerekezik a vasútállomásra, ${ }^{36}$ é beviszi a biciklit is.

A „hivatalában" múködik a településmenedzsment-rendszer: ${ }^{37}$ a biztonsági központ, a készletgazdálkodás, itt van a távïgyintézés internetes kapcsolódási pontja is.

- A biztonsági központ szerencsére nem jelez támadást, csak egy közeledó idójárási front jelent kockázatot. ${ }^{38}$

- A készletgazdálkodója jelzi, hogy a közösségi raktárban fogytán a konzervkészlet, és a váratlan helyzetekre való felkésziilés szabályzata szerint ${ }^{39}$ a jövó hónapban rendelni kell uijabbat. Lehiuz néhány tételt a felkinált listából, aะtán jóváhagyja.

- A táviigyintézój jelzi, hogy megjelent egy újabb környezetvédelmi pályázat, amelyen indulhatnak: a biológiai hulladékok has:nositása a fö téma. ${ }^{40}$

Körbekiuld egy elektronikus üzenetet, hogy ki tud részt venni a pályázatírásban. Hárman jelentkeznek. Videokonferenciára kapcsolnak, és elindul a virtuális megbeszélés. ${ }^{41}$

\section{Közös és eltérő elemek a megielenített jövőképekben}

A fenti négy jövớkép közös eleme az információs technológiák széles körú használata, az internetes munkavégzés vagy kapesolattartás általánossá válása. Hasonlóan közös elem a biztonsági témakörök felértékelődése. A mögöttes társadalmi kép rétegezett társadalmat mutat, melyben teljesen szabad a magánélet és a csoportalkotás.

Az eltérố elemek: a városi, kertvárosi vagy faluközösségi lakóhely, amelyet nem elsôsorban a fizikai elhelyezkedése határoz meg, hanem a benne élók jövedelmi helyzete. A leírások különbözô családszerkezetekról készültek, hogy a variációkat is láttassuk.

Arra törekedtünk, hogy ne csak a pozitív, hanem a beépülő kockázati elemeket is megmutassuk. A reálisan elképzelhetó jövót keressük.

\section{Összefoglalás}

Az intelligens otthon ,intelligenciája” - a három fejlódési víziónak megfelelóen mind a három esetben más-más módon alakul. Más IKT-eszközökön lesz a hangsúly, mivel az otthonoknak jelentôs mértékben eltérô funkciókat kell kielégíteniük.

\footnotetext{
${ }^{36}$ Az elóvárosi vasutak rekonstrukciója várható, mert energiatakarékos közösségi megoldást jelent.

${ }^{37}$ A településgazdálkodásnak sztenderd feladatai vannak, amelyek informatikai rendszerbe szervezhetók.

${ }^{38}$ A településbiztonsági központ nemesak hagyományos védelmi funkciókat lát el, hanem elemzi a meteorológiai és környezeti kockázatokat is.

${ }^{39}$ A tartalékkészlet megjelenik a közösség életében, mert tagjai tudatosan lekapcsolódtak a nagy cnergiahálózatokról, az úthálózatot sem fejlesztették tovább, és elsôsorban a helyi természeti környezettól függenek.

${ }^{40}$ A környezetvédelem országos és európai szintú központi támogatása várhatóan fennmarad.

${ }^{41}$ A közösség az informatikai hálózatokon keresztül kapcsolódik be a világ vérkeringésébe és a virtuális közösségekbe.
} 
A kínálatvezérelt fejlôdés valószínúleg komplexebb, az élet lehetô legtöbb területére kiterjedô ,intelligenciafunkciókat” eredményez. A szociális funkciók esetében elsősorban az egészségügyi „távszolgáltatások” hangsúlyosak. Az energiagondoknál az energiafelhasználás optimalizálása mellett az otthoni munkavégzést megkönnyítô eszközök válnak fontossá. A harmadik lehetốség az első bizonyos egyszerúsített változataként is felfogható. Az elsố és a második, illetve a harmadik és a második vízió között jelentoós koncepcionális különbségek vannak. A környezetintelligencia megteremtése mindhárom jövóképben meghatározó szerepet játszik.

Várhatóan két fejlődési szakasz lesz megfigyelhetô. Az elsóben az otthonok egyre nagyobb hányadában jelennek meg és terjednek el a háttérszolgáltatásokra és IK'T-eszközök alkalmazására épülő́ funkciók (reagáló épület, biztonság, szórakozás, munkavégzés, távfelügyelet). A második szakaszban a funkciók elsốsorban azért integrálódnak, mert hasonló technológiai alapokra épülnek, és a terjedésük alacsonyabb áron csak integráltan biztosítható. A társadalmi-gazdasági környezet azzal befolyásolhatja a spontán fejlődés irányát, ha - a szociális vagy energetikai eredetû társadalmi megtakarítások mértékének megfelelóen - támogatja ezeket az intelligens megoldásokat.

\section{Felhasznált irodalom}

Az otthon jövője. http://www.hg.hu/?action=cikk\&id=2128\&rovat_id=52

Az üzemanyag-takarékos autó és az intelligens otthon lepipálja a gyors internetet (2006. július 11.). http://www.hirado.hu/cikk.php?id=130874

Increasing an individual's quality of life via their intelligent home. www.steam.ualberta.ca/main/documents/home_research.pdf

Intelligens épület. http://www.p5.hu/termekek/intelligens.html

Intelligent buildings design and building management systems. http://www.businessballs.com/intelligentbuildingsdesign.htm

Intelligent Home from Home Controls. http://www.homecontrols.com/cgi-bin/main/co_disp/displ/pgrfnbr/461/sesent/00

Kalmár Miklós: Az intelligens otthon építészeti vonatkozásairól. http://arch.eptort.bme.hu/23/23kalmar.html

Németh Géza: Az intelligens ház (2006. július 12.). http://index.hu/ujlakas/hetrolhetre/intelligens/

ProSyst and Fraunhofer IMS: Intelligent Solutions for Home Networking. www.prosyst.com/success_stories/SuccessStory_ProSyst_Fraunhofer.pdf

Röcker, Carsten -Janse, Maddy D. -Portolan, Nathalie-Streitz, Norbert: User Requirements for Intelligent Home Environments: A Scenario-Driven Approach and Empirical Cross-Cultural Study (2006).

www.hitech-projects.com/euprojects/amigo/publications/roecker_et_al.pdf

Secure Entertainment - The Intelligent Home. http://www.silicon-trust.com/trends/tr_home.asp

Szalay Dániel: Intelligens ház Berlinben / Behálózott otthonok (2006. január 12.). http://www.fn.hu/index.php?action=nyomtat\&id=67\& $\mathrm{cid}=114803 \&$ layout $=$ no\&id $=67$

Toshiba: Visions Online: Digitális átállásként - Digitális otthon 2010-ben (2006 elsố negyedéve). http://ce.computers.toshiba-europe.com/Contents/Toshiba_ce/CE-HU/WHITEPAPER/ files/Visions-2005-12-Home-2010-CE.pdf

Wikipedia: Intelligent home. http://en.wikipedia.org/wiki/Intelligent_home 